山田 健夫*. 原田 直樹*.今井 清隆*

川烟 成夫*2 . 手塚 宏之*3 . 寺尾 精太*3

\title{
New Methods for Temperature Measurement and Their Applications to Steel Process
}

\author{
Takeo YAmAdA, Naoki HARAdA, Kiyotaka ImAI, \\ Shigeo Kawahata, Hiroyuki Tezuka and Seita Terao
}

Synopsis :

This report shows three new methods for temperature measurement and their applications to steel process.

(1) The effect of multiple reflection in the radiation thermometry was theoretically and experimentally studied, and a method for simultaneous measurement of both temperature and emissivity was developed and applied at the color coated strip process.

(2) The self-scanning photodiode array was applied to temperature distribution measurement. The characteristics of photodiode arrays were investigated, and the micro-computer based system is now operated for temperature measurement of the welding bead at the ERW process.

(3) The temperature distribution measurement system using optical fiber was developed, and applied at the exit of C.C. spray zone and under the mould.

\section{1. 緒言}

鉄鋼プセ久において，渺度測は最も基本的な計測 項目であり，熱電刘による接触式测温法，放射温度計に よる非接触式測温法が定兴している。一正，製品の高付 加価优化, 省エネルギ一化などの観点から, 測温精度の 向上, 高温域から低温域一の测温範囲の挫大, 一点から 多点への温度分有計測へのニーズが高まつている.

このよらな状沉の中で, 温度測技術の開発について 多面的にとり継寺こととした．以下に，最近開発を行つ た放射による温度計測法とその心用について次の 3 例を 紹介与る.

（1）多重仅射を利用した放射測温法の基礎検剖とカ

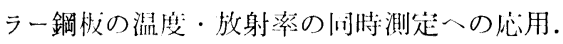

(2) $\mathrm{S}_{\mathrm{i}}$ イメージ七ンサ（リニア・アレイをを用いた

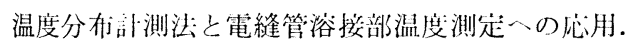

(3) 光ソァイぐを打いた温度分布計測法と連鋳鋼片 の温度測定一の份肘.

\section{2. 多重反射を利用した放射測温法}

放射測温において，特に低温・低放射率鋼板の測温で は，周囲熱源からの多乱及び放射率の值が常に問題とな り，従来から多重反射や参照熱源を利用した種々の放射 測温法が試みられている1) 5). 今回, 多重反射の効用を 検討することを目的として，解析・基礎実験を行い，カ ラ一鋼板の放射率・温度同時測定法についての検討を行 つた6)7).

\section{$2 \cdot 1$ 放射測温における多重反射の効果}

放射測温における多重反射の効用を検討するために, 各種鋼板の放射率角度依存性の測定及び平板を用いた多 重反射によるみかけの放射率の解析 · 測定を行つた。

$2 \cdot 1 \cdot 1$ 平板による多重反射の原理

多重反射による放射率向上の原理を Fig. 1 に示す. 紙面に垂直な 2 平面 $\mathrm{AB}$ (測定板)， $\mathrm{AC}$ (反射板) のな 与角度を $2 \theta$ とする，表面は完全鏡面反射するものと仮 定し, 点 $\mathrm{P}_{0}$ に角度 $\theta$ で入射した光の軌跡 $\mathrm{P}_{0}, \mathrm{P}_{1}, \mathrm{P}_{2}$,

昭和 58 年 10 月本会講演大会にて発表 昭和 58 年 11 月 9 日受付 (Received Nov. 9, 1983)

* 日本鋼管 $($ 株) システム技術研究所 (Systems and Control Research Center, Nippon Kokan K. K., 1-1 Minamiwatarida-cho Kawasaki-ku Kawasaki 210)

*2 日本鋼管 (株) 設備部 (Plant Construction and Engineering Department, Nippon Kokan K. K.)

*3 日本鋼管 (怢) 福川製鉄形 (Fukuyama Works, Nippon Kokan K. K.) 


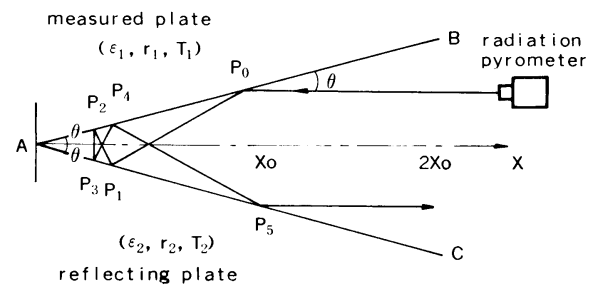

Fig. 1. Principle of multiple reflection.

…を求める. 各反射点 $\mathrm{P}_{\mathrm{i}}$ から放射されるエネルギー は, 求めた軌跡の逆を完全鏡面反射するものとすると, 測定される放射エネルギー $E$ は (1)式で表される.

$$
E=\varepsilon_{1}^{*} \cdot E b\left(T_{1}\right)+\varepsilon_{2}^{*} \cdot E b\left(T_{2}\right)
$$

ここで, 鋼板及び反射板の（放射率, 反射率, 温度）を それぞれ $\left(\varepsilon_{1}, r_{1}, T_{1}\right),\left(\varepsilon_{2}, r_{2}, T_{2}\right), \mathrm{AB}, \mathrm{AC}$ 面上で の反射回数を $n, m$ ，また，温度 $T$ に打ける黒体の放射 エネルギーを $E b(T)$ とすると， $\varepsilon_{1}^{*} ， \varepsilon_{2}^{*}$ はそれぞれ (2), (3)式で表される.

$$
\begin{aligned}
& \varepsilon_{1}^{*}=\varepsilon_{1} \cdot\left\{1-\left(r_{1} \cdot r_{2}\right)^{\mathrm{n}}\right\} /\left\{1-\left(r_{1} \cdot r_{2}\right)\right\} \cdots \cdots \\
& \varepsilon_{2}^{*}=\varepsilon_{2} \cdot r_{1} \cdot\left\{1-\left(r_{1} \cdot r_{2}\right) \mathrm{m}\right\} /\left\{1-\left(r_{1} \cdot r_{2}\right)\right\}
\end{aligned}
$$

$E$ は, $T_{1}=T_{2}$ の場合 $(4)$ 式で, $T_{1} \gg T_{2}$ の場合 $(5)$ 式 で表される。

$$
\begin{aligned}
& E=\left(\varepsilon_{1}^{*}+\varepsilon_{2}^{*}\right) \cdot E b\left(T_{1}\right) \\
& E=\varepsilon_{1}^{*} \cdot E b\left(T_{1}\right) \ldots \ldots \ldots . . .
\end{aligned}
$$

\section{$2 \cdot 1 \cdot 2$ 実験及び結果}

測定対象板で容器を作り，水を入れて沸点を保つたま 屯 $\left(T_{1}=T_{2}=100^{\circ} \mathrm{C}\right)$, 焦電型放射温度計（波長 9 12 $\mu \mathrm{m})$ を用いて放射率の角度依存性及びみかけの放射率 の測定を行つた.

Fig. 2 は測定角 $\theta$ を連続的に变えて測定した各種鋼 板の放射率，Fig. 3 は反射板としてアルミ板を用いた 場合の, カラー鋼板 (薄緑) とブライト板のみかけの放 射率 $\left(\varepsilon_{1}^{*}+\varepsilon_{2}^{*}\right)$ の測定結果の一例である. 実線が类測值 破線は Fig. 2 の結果を用いて(1)(2)(3)式に従つて 計算した值である. また, Fig. 3 から, 測定角 $\theta$ の減 少にともない, 又かけの放射率が向上することがわか る. 計算值と実測值がよく一致して扣り，測定角 $52^{\circ}$ (B) $, 32^{\circ}(\mathbf{C}), 24^{\circ}$ (D) 付近でみかけの放射率が不連 続に増加しているのは，表面の反射特性が鏡面的である ことを実証している.

\section{$2 \cdot 2$ カラー鋼板の温度・放射率同時測定}

カラー鋼板製造ラインでは，塗料の塗布後の焼き付け 温度は塗膜の性能（加工性・耐候性・防食性）を決定す る重要な指標である。一方，品種による放射率の違いが 大きく，放射率の影響を受けない测温法に対するニーズ

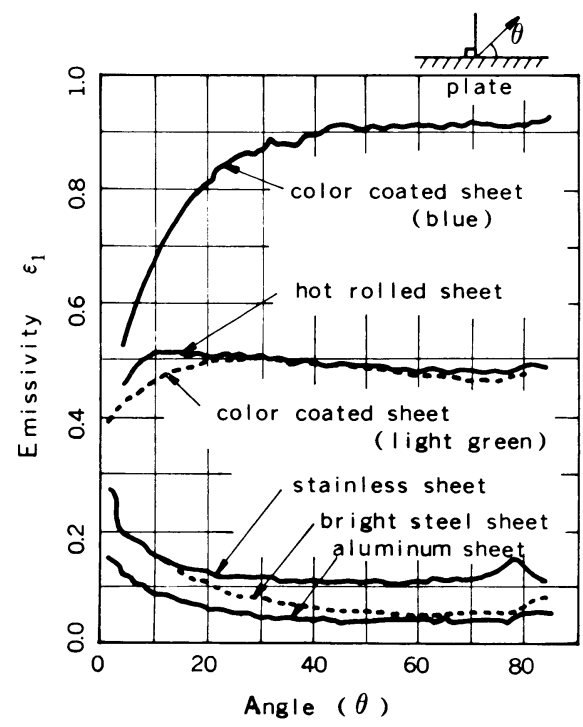

Fig. 2. Angular characteristic of emissivity.

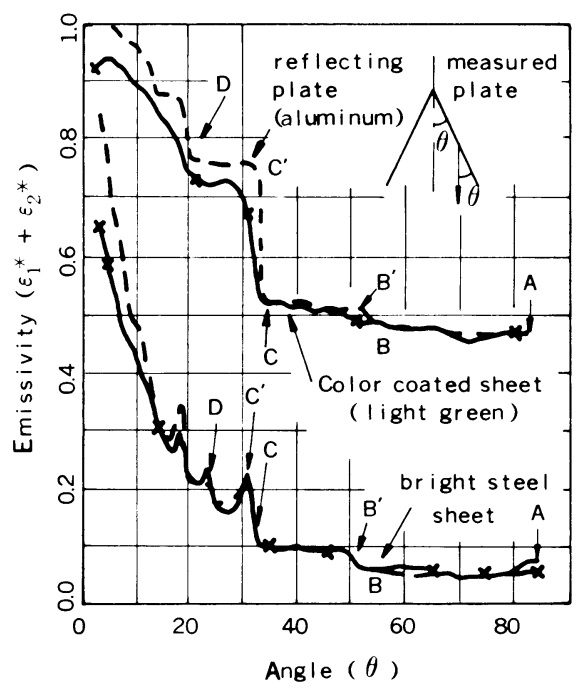

Fig. 3. Examples of emissivity $\left(\varepsilon_{1}^{*}+\varepsilon_{2} *\right)$ measurement.

が高い，今回，棈造が簡単な平面反射板による多重反射 を利用した温度・放射率同時測定法についてカラ一鋼板 製造ラインで検漷した。

\section{$2 \cdot 2 \cdot 1$ 温度: 放射摔测定の原理}

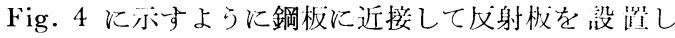
放射温度計で $P_{1}$ 㸃，Q点を测定する， $P_{1}$ 㸃で测定され る放射エネルギー $E_{\mathrm{p}}$ は, 反射板の盕度 $T_{2}$ が鋼板の温 度 $T_{1}$ に比べて十分低く，その放射エネルギーを無祝で 


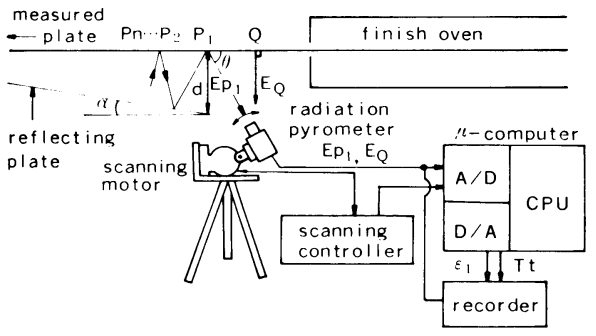

Fig. 4. Measurement system.

きるとすると，鋼板ト:の $\mathrm{P}_{1}$ 点から $\mathrm{P}_{\mathrm{n}}$ 点までの各点か ら発する放射束が鋼板と反射板の問で多重反射した值

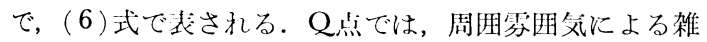
音の影響を受けない放射温度计を用い水ば，(7)式で表 される。

$$
\begin{aligned}
& E_{\mathrm{P}}=\varepsilon_{1} \cdot \begin{array}{c}
1-\left(r_{1} \cdot r_{2}\right)^{\mathrm{n}} \\
1-r_{1} \cdot r_{2}
\end{array} E b\left(T_{1}\right) \\
& E_{\mathrm{Q}}=\varepsilon_{1} \cdot E b\left(T_{1}\right) \cdots \cdots \cdots \ldots \ldots \ldots \ldots \ldots \ldots \ldots \ldots \ldots
\end{aligned}
$$

(6) (7) 式より (8)式が得られる.

$$
E_{\mathrm{p}} / E_{\mathrm{Q}}=\left\{1-\left(r_{1} \cdot r_{2}\right)^{\mathrm{n}}\right\} /\left(1-r_{1} \cdot r_{2}\right)
$$

鋼板上の反射回数 $n$ は, 文射板之放射温度訣の幾何学: 的配置 $(\alpha, \theta, d)$ により決末る. 従つて, 反射板の反射 率 $r_{2}$, 反射回数 $n$ を旡知々す机ば $(8)$ 式及びキルヒホ フの法則 $(\varepsilon+r=1)$ を用いて鋼板の温度 $T_{1}$, 放射治 $\varepsilon_{1}$ が算出される.

\section{$2 \cdot 2 \cdot 2$ 実験及び絬果}

熱处理炬出側に, 鋼板に近接 $(d=20 \mathrm{~cm})$ して, 父射 板 (アルミ板) を $\alpha=6^{\circ}$ 傾けて設湿し, PbS 放射温度 計（分光感度 1.5 2.7 $\mu \mathrm{m}$ ) 及びモータとコントローラ からなる起查装䍜を用い， $\mathrm{P}_{1}\left(\theta=60^{\circ}\right), \mathrm{Q}\left(\theta=90^{\circ}\right)$ を 測定した. 温度計出力倠 $E_{\mathrm{P}}, E_{\mathrm{Q}}$ 上り，マイコンを用 いて $\varepsilon_{1}, T_{1}$ を算出した。文射板文射率は基整坐験によ b) $r_{2}=0.9$ 七し，文射的数 $n=6$ として草算した。

下涮 3 種類の鋼板について赺ラインで測定を行つた。 $\mathrm{A}$ : カラー鋼板 (炎色), B : カラー鋼板 (ベージュ), $\mathrm{C}:$ :シンクロメタルの冷延鋼板湎i

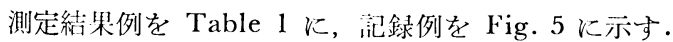
本方法によつて求めた滥度 $T_{\mathrm{t}}$ と接触式温度部 $T_{\mathrm{s}}$ と の差は, 3 種類の鋼板について $\pm 3^{\circ} \mathrm{C}$ 内であり, 放射 率 $\varepsilon_{1}$ も信頼性が宲いと思われる.

\section{3. リニア・アレイによる温度分布計測}

$\mathrm{S}_{\mathrm{i}}$ 光検出素子を一次元に多数配列した $\mathrm{S}_{\mathrm{i}}$ イメージセ ンサ（リニア・アレイ）は，铁鋼ブロセ久においても70

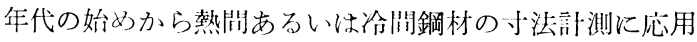
され効果をあげている8)〜10)。これらの応用がイメージ
Table 1. Results of measurement.

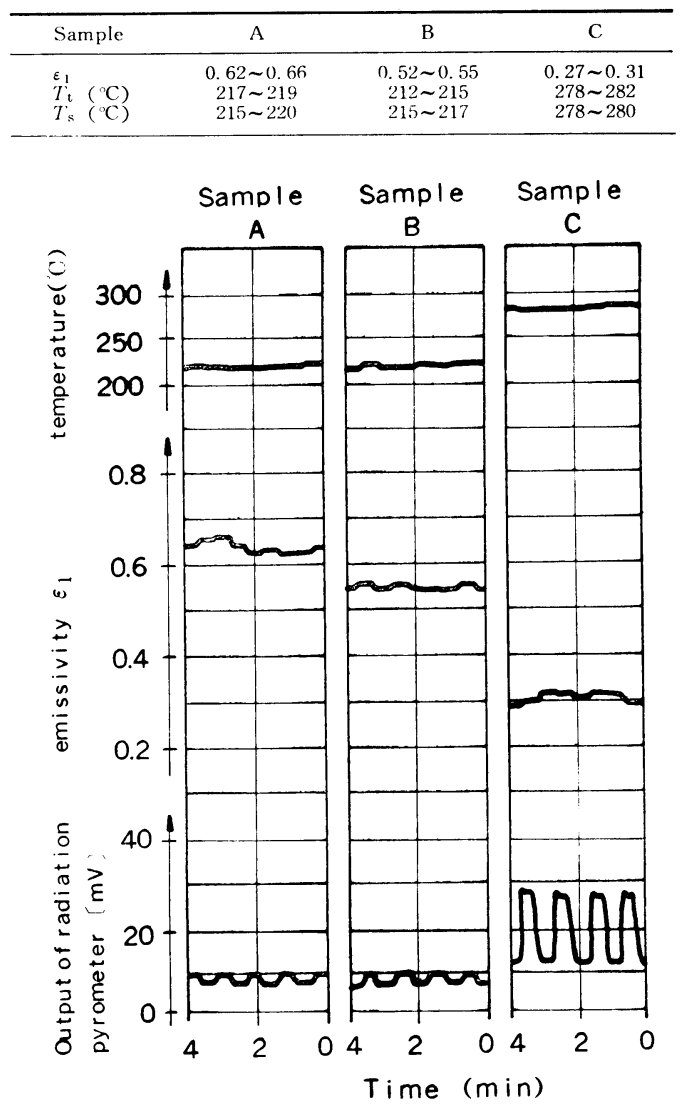

Fig. 5. Examples of recorder outputs.

センサのディジタルな機能を利用しているのに対し，最 近アナログの機能に着目し温度分布計センサとして利用 する研究開発が進められている11) 14).

今[川，マイコンと組及合わせたシステムを用いて $\mathrm{S}_{\mathrm{i}}$ 亿 メージセンサの温度分布計としての可能性について実験 公及び圧延ラインでの計測実験を通じて確認した ${ }^{15) 16)}$. その結果に基づき, 電縫管溶接部温度測定システムの設 供化を行い，現在順調に稼動している。

\section{$3 \cdot 1$ リニア・アレイの概要}

リニア・アレイ素子の配列状況を Fig. 6 に示す. 感 度及び空間分解能は素子の大きさ, 間隔及び素子数で決 まる. 䋕子の分光感度は $0.8 \mu \mathrm{m}$ 付近にピークがある17) ので放射温度計としての応用が可能である. 試作した温 度分布計の構成を Fig. 7 亿, 実験に使用した 3 種のリ ニア・アレイ・カィラ (MOS 型) の仕様を Table 2 に示す. 測温対象の輝度分布をレンズ系を通してリ= ア・アレイ上に結像させる. 放射輝度に比例した蓄積電 荷が駆動回路により一定周期 $t_{\mathrm{S}}$ で電子的に走査され, 


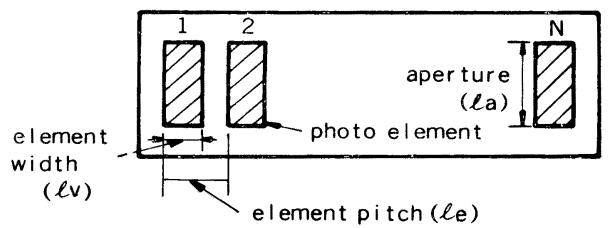

Fig. 6. Photodiode element.

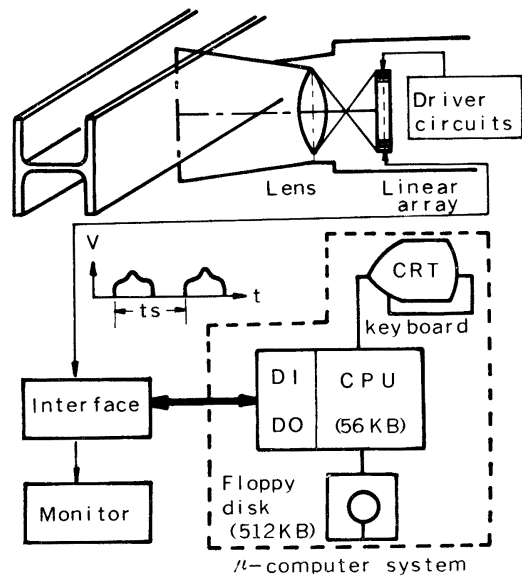

Fig. 7. Block diagram of the test system.

Table 2. Specifications of the linear array used in the test system.

\begin{tabular}{lrrr}
\hline \multicolumn{1}{c}{ Camera } & 1 & 2 & 3 \\
\hline Number of elements $\mathrm{N}$ & 1024 & 1024 & 1024 \\
Aperture $l_{\mathrm{a}}(\mu \mathrm{m})$ & 464 & 425 & 25 \\
Element pitch $l_{\mathrm{f}}(\mu \mathrm{m})$ & 28 & 25 & 25 \\
Element width $l_{\mathrm{v}}(\mu \mathrm{m})$ & 16 & 13 & 13 \\
\hline
\end{tabular}

ビデオ信号として出力される. 走査周波数の制御, 出力 電压の読㕛取り, 温度変換及び温度分布の解析のために マイコン・システムを用いた.

\section{$3 \cdot 2$ リニア・アレイの特性}

\section{$3 \cdot 2 \cdot 1$ 温度出力特性}

リニア・アレイの出打電生は走査周波数によつて制御 することができ，電压 $V$ は走查周波数 $f$ に反比例し (9) 式で表すことがでさる。

$$
V \propto 1 / f
$$

走查周波数をパラメータとして盕度と出力電压の関係を 測定した結果を Fig. 8 に示す. 术查周波数を $6 \mathrm{~Hz}$ か ら $800 \mathrm{~Hz}$ の間で選択すればー定絞りの光学系で 500 $1100^{\circ} \mathrm{C}$ の広い範囲にわたつて測温できることがわか る. また，走查周波数の選択により，ビデオ・アンプ, $\mathrm{A} / \mathrm{D}$ 変換器の特性の最良の点に出力電圧レベルを合わ せることも可能である.

温度と出力電圧の関係はウィーンの式に奏效波拄の考

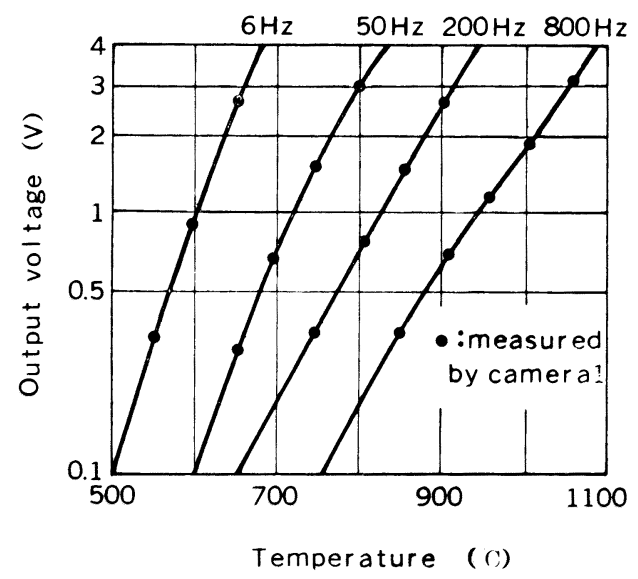

Fig. 8. Calibration curves of the linear array as a function of the scanning frequency.

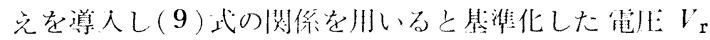
が(10)式で住される。

$$
V_{\mathrm{r}}=\frac{f_{\mathrm{s}}}{f_{\mathrm{r}}} \cdot V_{\mathrm{s}}-A_{0} \lambda_{\mathrm{e}}^{5} \cdot \exp \left(c_{\mathbf{2}} / \lambda_{\mathrm{e}} \cdot T\right)
$$

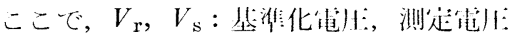

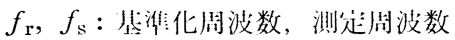

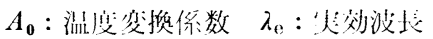

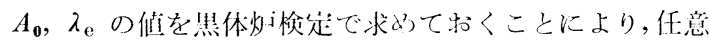

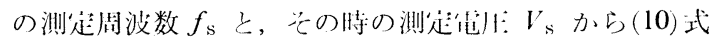
を打いて测定温度: $T$ を求るることができる。

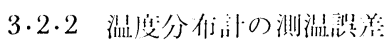

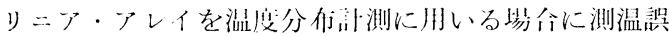

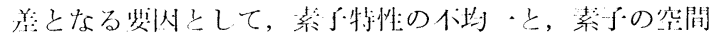
分解能がある。

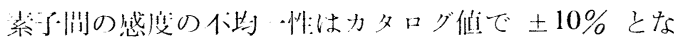

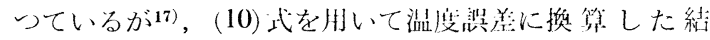
果, $1000^{\circ} \mathrm{C}$ で $\pm 10^{\circ} \mathrm{C}, 600^{\circ} \mathrm{C} て ゙ \pm 4^{\circ} \mathrm{C}$ 程度であり,

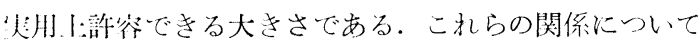

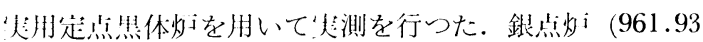
C) の例ではばらつきは $\pm 8^{\circ} \mathrm{C}$ 内であつた ${ }^{16)}$ 。た，

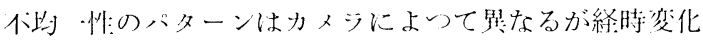

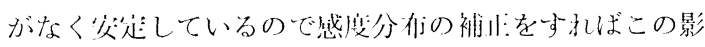
掣を低娍尗ることが川能である。

リニテ・テレイの空间分解能は $\mathrm{S}_{\mathrm{i}}$ 基板付での光䒜子 の洨透深さにより影犁を受ける。川視邻域でのク口久卜 一クの影脑は 1〜2 䋕子といわれているのに対し ${ }^{18)}$,

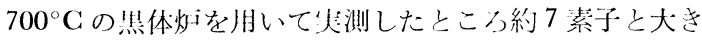
な任を得た15)。波长の长い近赤外领域ではクロストーク が発生しし它润分解能が低ドするので材料端部の盕度分布

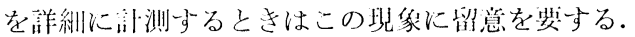




\section{3 電縫管溶接部温度測定システムの概要}

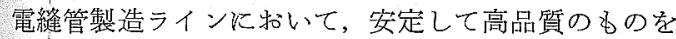
製造するためには，溶接条件を管理する必要があり，溶 接大力制御を行うための最も重要なパラメータの一つは 溶接部の温度である. 一方, 溶接部は数 $\mathrm{mm}$ と細く, 通常の放射温度計で安定した情報を得るのは困難である ばかりでなく，溶接加熱部の温度は高入熱側では融点に 近づき温度は飽和する傾向を示し ${ }^{19)}$ ，定常溶接時は入熱 の高低を判断するのは不可能でかる。

今回, リニア・アレイ温度分布計システムを溶接部の 温度測定に適用した，造管の走行方向に刘して重直の温 度分布を検出することにより，溶接部温度の安定した検 出，及び飽和特性を補らための情報を信号好理により容 易に求めることが可能となつた.

本システムの構成を Fig. 9 飞示す. Table 3 K本シ ステムの仕様をまとめている.リニア・アレイからのビ デオ出力信号は 8 ビット A/D 変換され, デジタル信号 としてカメラ・インターフェースに送られ，温度変換テ ーブル（ROM に内裁）を用いて温度が求められる。

A/D 変換によるデジタル䛊差を小さくするため 2つの 走查周波数を用い高温部と低温部を交互に検出し，合成 により温度分布を得ている，溶接部の温度分布は TV 画面で常時モニターされるとともに信号処理によりピー ク温度及び入熱量值に等価と考えられる基準温度以上の 面積值が制御信号としてアナログ出力される．TV 画面 の出力の一例を Photo. 1 に示す.

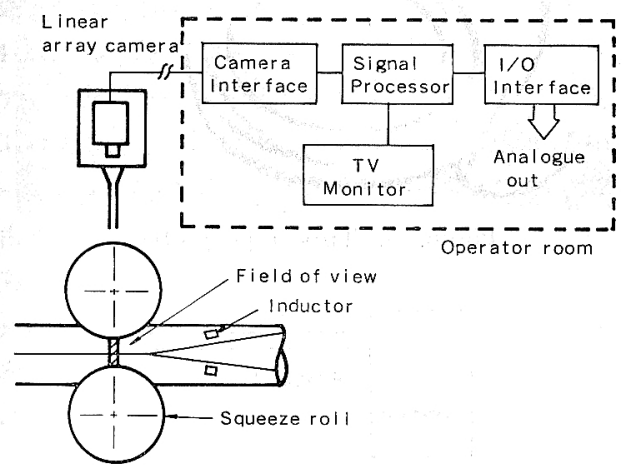

Fig. 9. Block diagram of Linear array System for ERW.

Table 3. Specifications of Linear array system for ERW.

\begin{tabular}{ll}
\hline Range (accuracy) & $1100 \sim 1500^{\circ} \mathrm{C}\left( \pm 10^{\circ} \mathrm{C}\right.$ at $\left.\varepsilon=1\right)$ \\
Number of element & 512 \\
Temperature resolution & within $2.5^{\circ} \mathrm{C}$ \\
Field of view & $30 \mathrm{~mm}(0.06 \mathrm{~mm} /$ element) \\
Sampling interval & Min. 0.08 (Analog out) \\
& $0.5 \sim 5 \mathrm{~s}$ (TV display) \\
\hline
\end{tabular}

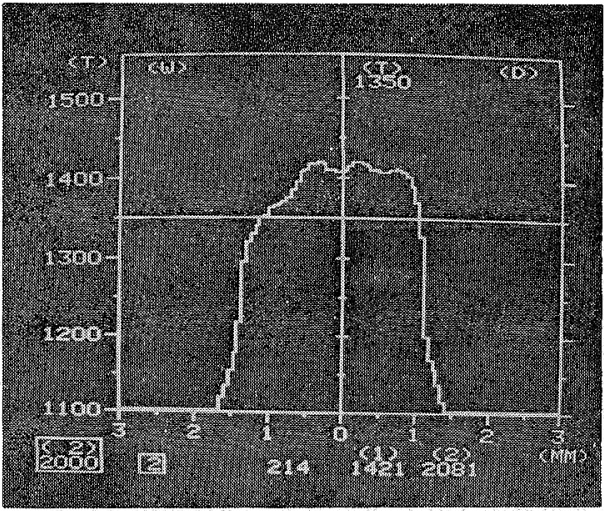

Photo. 1. An example of ERW's seam temperature distribution on TV display.

Table 4. Specifications of fiber scanning type system.

\begin{tabular}{ll}
\hline Range (accuracy) & $800 \sim 1300^{\circ} \mathrm{C}\left( \pm 10^{\circ} \mathrm{C}\right)$ \\
Principle & $\mathrm{T}_{\mathrm{wo}}$ color pyrometer \\
Wave length & $\lambda_{1}=0.85 \mu \mathrm{m}, \lambda_{2}=1.0 \mu \mathrm{m}$ \\
Optical rod & $1.3 \mathrm{~mm}^{\phi}, \mathrm{NA}=0.28$ \\
Bundle fiber & core $: 100 \mu \mathrm{m}^{\phi}, \mathrm{crad}=140 \mu \mathrm{m}$ \\
Pulse motor & $0.36^{\circ} /$ pulse \\
Scanning cycle & $15 \mathrm{~s}$ \\
\hline
\end{tabular}

\section{4. 光ファイバ走查による連鋳鋼片温度 分布計測}

光ファイバ走查式温度分布計は，近年ますすす高品質 化を志向する鋼の連鋳プロセスに特いて，鋳片の品質管

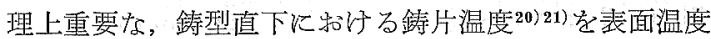
分布の形でとら劣るために開発された22)，従来，鋳型直 下部の測温は, 鋳片の顕熱やスプレー水，水蒸気の存在 などの計測上の㥶環境条件 ${ }^{23)}$ と，検出器を設置するため の十分な空間がないなどの設置上の制約から，実用的な 方法が確立されていなかつた。本盜度幽は，これらの問 題を光ファイバを用いて鋳片の熱放射光を連鋳機外へ導 き出すことで解決した。

\section{1 原理と構成}

本温度計の精成 Fig. 10 亿, 仕様を Table 4 に示 す.アレー状に配列されたオプチカルロッドに入射した 鋳片の熱放射光は，バンドルファイバルより連鋳機外に 導か机る。才プテカルスキャナは。属明したオプチカル ロッドをパルスモータで回転させることにより円周上に 配列した入射光を 1 点ずつ機栈的に走查し，测定点ごと の放射光を時分割的に次の二色演算系に入力する. 二色 演算系ではこの光信号をハーフミラーで二分した後それ ぞれ光学フィルタ通して戦波長信号化し， $S_{\mathbf{i}}$ フォト セルで光電変換している。各波長の信号淄幅， A/D 変換の後にマイコンに入力さ敞て二色演算され, 多点温 


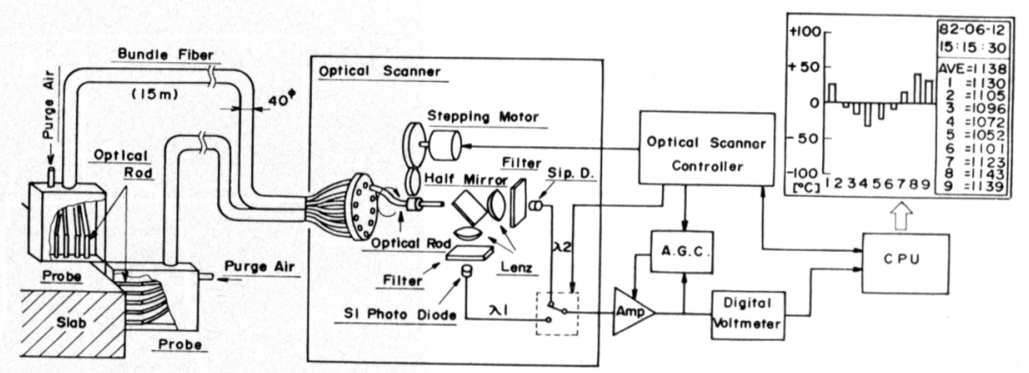

Fig. 10. Optical fiber scanning type surface temperature profile meter system.

度分布の形で CRT 及びプリンタに出力される.

光学系は先端に耐熱性をもたせるため, ファイバ構造 の石英ロッドを用い, これに $15 \mathrm{~m}$ のバンドルファイパ を固定給合させてオプチカルスキャナに導いた. $800^{\circ} \mathrm{C}$ の鋳片からの放射光受光パローが $-30 \mathrm{dBm}$ に対して, 光電変換部への入射パワーは $-46.5 \mathrm{dBm}$ となり, 本温 度計に使用した受光素子感度が $-50 \mathrm{dBm}$ であるから， $800^{\circ} \mathrm{C}$ 以上の測温が可能である.

オプチカルスキャナは, 上部にバンドルファイバを接 続するコネクタを 10 個円周上に配置し, 屈曲した石英 ロッドをパルスモータで回転させ, 光学的走査を行う. パルスモータ・ステップにして \pm 2 ステップ以内の光 軸のずれは，二色演算出力に影響を与えない．

本温度計の受光端部は二種類のタイプを開発した。 Photo. 2 はアレー型のプローブで, $100 \mathrm{~mm}$ のロッドを $15 \mathrm{~mm}$ 間隔で 6 本並列配置してある.このプローブを 2 組使うことで鋳片ューナー部 2 面の温度分布を同時測 定できる. Photo. 3 はチューブ型プロープで $1000 \mathrm{~mm}$ のロッド 3 本をそれぞれステンレス・フレキシプルチュ ーブに通してある. このタイプでは連鋳機内に入るのが $22 \mathrm{~mm} \phi$ のチューブのみなので，わずかなすきまにも自 由に設置できる利点がある.

信号処理系はマイコンを用い, 二色演算, アンプゲイ ンの調整, 及びデータの平均化処理を行ら。測温結果は CRT 及びプリンタに温度分布の形で数值及びグラフ表 示される. また, 鋳型直下のように, パウダーフィルム やミストなどの外乱要因の多い環境下では測定值は大き くばらつくか゚，10〜20 周期分の 測 定值の移動平均をと ることにより，これらの外乱成分を除去した.

\section{$4 \cdot 2$ 実験結果}

$4 \cdot 2 \cdot 1$ スラブコーナー部測温実験

2 組のアレー型プローブ（測定点数 6 点及び 3 点）を スラブ CC の出口に Fig. 11 のように直角に配置し, スラプューナーの長・短辺面の温度分布を測定した. 結

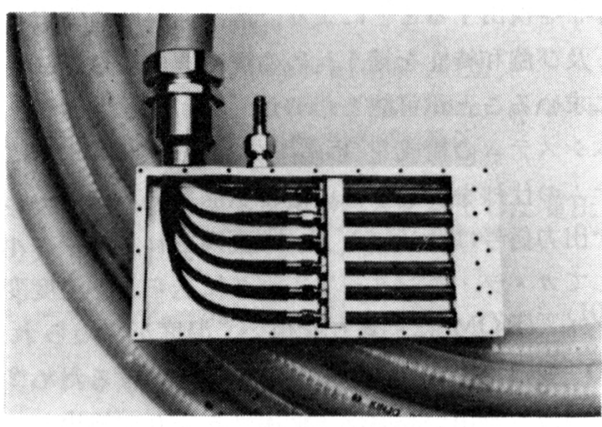

Photo. 2. Array type probe.

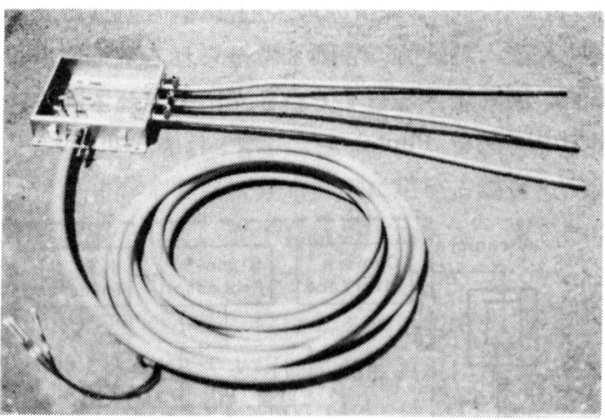

Photo. 3. Tube type probe.

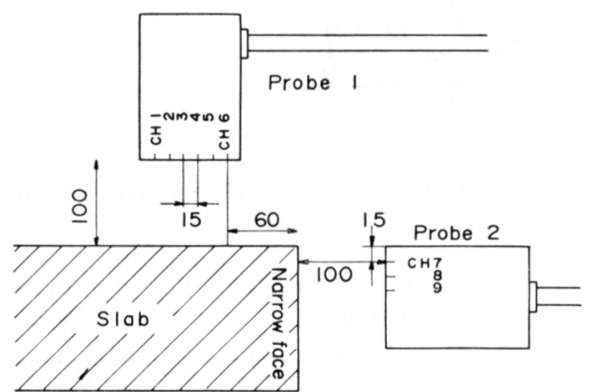

Fig. 11. Arrangement of testing probe at slab corner. 


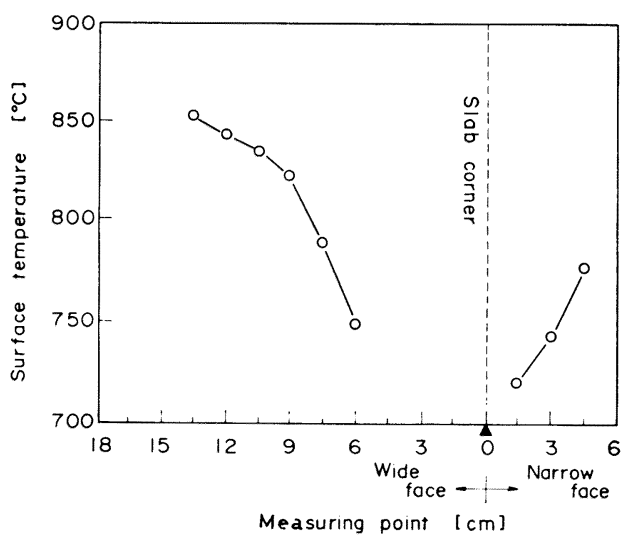

Fig. 12. Test result of temperature profile of C.C. slab corner.

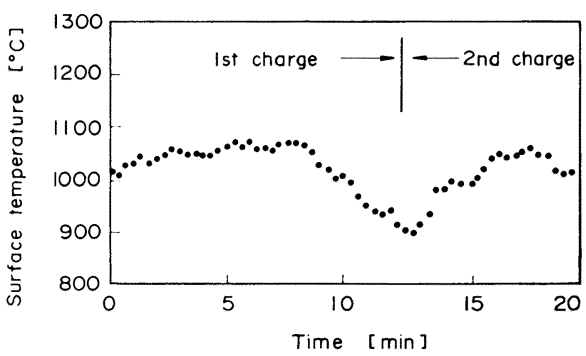

Fig. 13. An Example of C.C. slab temperature measured under mould.

果はFig. 12 に亦すよらにスラブューナーに向から温 度降トの様子がみられた。

$4 \cdot 2 \cdot 2$ 鋳型㨁下測温农験

アレー型，チューブ型の街プローブについてスラブ CC の鋳型直ドの测温テストを行つた。鋳型值下にはサ ポートロール，スプレーノズル等が密集しており，据付 自由度の大きいチューブ型プローブのブが容易に取り付 けられた。いずれのプローブも 1 週间以上の連続使用に 耐えた．Fig. 13 は测定結果例である。データのばらつ きを 15 点 (5 min) の移動平均をとることで平滑化し た、鍋交換による鋳扸温度低卜が明睹に読みとれる。
て 3 例を紹介した。いずれも基礎技術は確立したので， 今後は改良灾用技術の開発を推進したいと考える。

\section{文献}

1 ) 井内徹, 大野二郎，草鹿履一郎：鉄と鋼，61 (1975), p. 2076

2 ) 井内 徹：鉄と鋼，65(1979)，p. 97

3 ) 划村洋一: 計測自動制御学会第 46 回温度計測部 会 (1981)

4) T. Iuchi and $R$. Kusaka: 6th Symposium on Temperature Its Measurement and Control in Science and Industry (1982) Mar.

5 ) 井内 徹, 田中富三男, 渡辺国俊: 鉄と鋼, 69 (1983), S 1156

6 ) 原田直樹, 今井清隆, 山田健夫：鉄と鋼，69 (1983), S 1223

7 ) 原田直樹, 今井清隆, 山田健夫：鉄之鋼，69 (1983), S 1224

8 ) D. L. Burk and N.F. Simic: Iron and Steel Engineer, 55 (1978) 7, p. 43

9 ) D. Larin: Association of Iron and Steel Engineers Annual Convention (1978)

10) M. Guegan: Rev. Métall-CIT, 78 (1981), p. 309

11) P. Bohländer: Stahl Eisen, 97 (1977), p. 927

12) H. J. Kopineck: Stahl Eisen, 101 (1981), p. 267

13) 長坂浩安，水野正志，宇津野光朗：電気製鋼，52 (1981), p. 239

14）菱杊功，鈴木利房，片山憲作，井手敏彦：第 22 回計測自動制御学会学術講演会 (1983), p. 1616

15) $T$. Yamada, $N$. Harada and $M$. Koyanagi: 6th Symposium on Temperature Its Measurement and Control in Science and Industry (1982) Mar.

16) 山田健夫，原田直樹，小柳弥夫：計測と制御，21 (1982), p. 1050

17) EG \& G Reticon: Catalogue (1981)

18) $R$. Hopwood: SPIE, 230, Minicomputers and Microprocessors in Optical System (1980)

19）京極哲朗, 高間館千春, 堀田一之, 達脇正雄, 根 本 進: 住友金属, 35 (1983)，p. 61

20）野崎 努, 松野淳一, 村田賢治, 大井 浩, 児玉 正範：鉄之鋼，62(1976)，p. 1058

21）原田慎三，草野昭彦，三隅秀幸，射平由雄：鉄と 鋼，62(1976)，S 545

22）松村勝已，寺尾精太，手塚宏之，井原 将，吉村 耕三，板井靖生：鉄と鋼，68 (1982)， S 852

23) 田村洋一：計測と制御，21 (1981)， p. 1039

\section{5. 結}

最近行つた放射による温度㖕測法の新しい技術につい 